\title{
A study of the level of management knowledge of woodcraft artisans in Indonesia
}

\author{
Slamet Subiyantoro ${ }^{{ }^{*}}$, Edy Tri Sulistyo ${ }^{2}$, Nanang Yulianto ${ }^{3}$, Nadia Sigi Prameswari ${ }^{4}$ \\ 1, 2, 3, 4 Sebelas Maret University, Surakarta, Indonesia
}

\section{Keywords \\ Management \\ Social \\ Professional \\ Woodcraft}

Received: 21 December 2016

Accepted: 11 April 2017

Published: 9 October 2017

\begin{abstract}
This study aims to examine the level of management knowledge of the woodcraft artisans in Yogyakarta, Indonesia. This study belongs to qualitative descriptive research. It was conducted at industrial woodcraft center in Patuk Village, Gunung Kidul Regency, Yogyakarta, Indonesia. Sixty-two respondents were selected randomly out of 627 people profess woodcraft artisans from 7 locations. Purposive sampling was used, and the data was collected through questionnaires, interviews, and observation methods. Then, the data were analyzed using interactive techniques, including data reduction, presentation, and verification. The result shows that the knowledge level of the wood artisans for the management basic concepts is categorized as good (71.5\%), for the business planning is categorized as adequate (69.1\%), and for the business, organization is also adequate (61.5\%). Furthermore, the level of knowledge for the briefing aspect is good (76.9\%) and for the quality control is modest (57.3\%). Overall, the level of management knowledge is still categorized as modest since out of four aspects; the briefing is the only good aspect. Meanwhile, the other three aspects belong to the adequate and modest level. This subject is caused by the socio-cultural factor in the society, which tends to be more socio-collective than professional. The previous researches mainly focus on management and art craft production. This paper provides the information to connect the subject to the knowledge of management for artisans.
\end{abstract}

(C) 2017 The Author(s). Published by TAF Publishing.

\begin{abstract}
INTRODUCTION
There are many artisans in the rural and urban areas which belong to the small and medium business scales in traditional and modern forms. Many researchers have written about the elements of the association of art craft with management, yet research that directly related to management of the business is still limited. Nurkhasanah (2002) states that Art and Craft Studies has discussed the aspects of the process while Rushartono (1996) mentions about production. Meanwhile, Subiyantoro and Aniek (2012) discuss the economic value and Sulistya et al. (2015) tells about the design. Furthermore, Subiyantoro and Sulistyo (2007) refers to the shape and style, and Subiyantoro \& Aniek (2005) mention about the signification. It can be concluded that a specific study of management knowledge for artisans is still insufficient until now. In this context, management knowledge is essential to be analysed in order to increase business productivity. Subiyantoro (2016) states that the behaviour of the artisans in handling challenge or problems is inseparable with their knowledge and experience. Therefore, basic knowledge of management is very significant for business management behaviour.

There is a wide gap between the knowledge of management system and the real application of management. Thus, a resolve which can give positive impact and increase the business management performance of the small and medium enterprises of woodcraft is
\end{abstract}

\footnotetext{
${ }^{*}$ Corresponding author: Slamet Subiyantoro

†Email: s.biyantoro@yahoo.co.id
} 
needed. This includes the ability to face global market and to change the cultural viewpoint from farming to entrepreneurship standpoint. Based on the background, the objective of this research is to analyse the level of business management knowledge of the woodcraft artisans in Indonesia, especially in the city of culture like Yogyakarta. This study purposes to define the preparation of the artisans in managing a business for the global market.

This research has significances both in theoretical and practical terms. As a researcher, I write this paper to provide broader knowledge regarding the business management knowledge of woodcraft for the artisans, especially in Java region. This research also can be a reference for the municipal government, such as the Ministry of Industry, in making policy related to community empowerment in managing craft entrepreneurship. As a lecturer of Education Department, I want to provide a new subject for Art major. Furthermore, business management can be a beneficial subject for the students to study. I also purpose to provide wider knowledge for other researchers in analyzing the business management of woodcraft artisans. I wish this research can be a contribution to other studies of similar discipline.

This study discusses the management aspects. A scholar named Terry (1993) defines management as a particular process consists of planning, briefing, and controlling actions which are conducted to set and achieve the goals which have been determined through the use of human resources and other resources. Besides, the functions of management include the planning, organizing, briefing, and controlling aspects (Conkright, 2015). I add a brief explanation of the aspects of management.

The first aspect is planning. It is the basic management function since organizing, briefing, coordinating and controlling need to be planned first. It has dynamic form in which it is flexible to be changed anytime depends on the current situation. According to Fayol (1949), planning is the first step definition for an organisation to achieve a certain goal. It also relates to the efforts in anticipating future tendencies and the decision of a precise strategy or tactic in achieving the goal of the organisation.

Organizing is the second aspect. It functions to establish a structure of integrated components so that the interrelationship is restrained to the whole. Organizing can be defined as the determination of the jobs to be done, the grouping of the tasks which later distributed to the employees, the arrangement of departments (subsystems) and the establishment of relationships.

The third management aspect is briefing. According to Terry (1993), the briefing is a construction for making all of the group members willing to work together sincerely and for achieving the goals passionately based on the plan and the efforts of the organisation. It functions to guide, motivate, and arrange all of the activities and the tasks from the leader in running a business.

The last management aspect is controlling. Based on Koontz et al. (1991), it is a measurement and revision of the jobs done by the employees in achieving the goals made from the constructed plans. Besides, Hasibuan (2002) stated that controlling is the arrangement process of various organizational factors in keeping the activities on the plan and schedule.

\section{RESEARCH METHOD}

This study belongs to the qualitative descriptive research (Nasution, 1988) which is conducted in the industrial woodcraft center in Patuk Village, Gunung Kidul Regency, Yogyakarta, Indonesia. The samples, which are 62 respondents, were selected randomly out of 627 people profess woodcraft artisans from 7 locations. The data was taken from various sources, including the informants who are the woodcraft artisans and public figures, 
the location and events, and the documents/archives. The data was collected through open and close questionnaires, interview, and observation methods. The observation, interview, and documentation processes were conducted according to the research purpose to make it into purposive sampling. The observation was conducted in industrial woodcraft center from 7 locations.

Bogdan and Steven (1993), Spradley $(1979,1980)$ mentions that for having a deeper analysis, a direct observation was conducted which later was completed by the documentation process. Miles and Michael (1984) explains that a validation stage is carried on with informants review and data recheck in order to increase data validity. In this paper, the employed analysis belongs to the interactive model. The data was analysed continuously using interactive techniques, including data reduction, presentation, and verification until a whole conclusion can be settled.

\section{RESULTS AND DISCUSSION Results}

TABLE 1 . The knowledge level of woodcraft artisans in management

\begin{tabular}{llcc}
\hline \hline Item & Statement & Amount of Respondents & $\%$ \\
\hline & Already know & 52 & 75.4 \\
$\begin{array}{l}\text { Knowing the } \\
\text { definition of }\end{array}$ & Just heard of it & 10 & 14.5 \\
management & & & \\
& Don't know & 7 & 10.1 \\
Total & & 69 & 100 \\
\hline \hline
\end{tabular}

Table 1 show that many of the artisans (75.4\%) already know about management and only $14.5 \%$ of them who just heard about it when they filled in the questionnaires. The remaining people $(10.1 \%$ ) have not known about management yet. Thereby, the average number of the artisans has known the management concept. It means that they recognize that their businesses should be managed with the management concept.

TABLE 2 . The knowledge level of woodcraft artisans in management aspects

\begin{tabular}{llcc}
\hline \hline Item & Statement & Amount of Respondents & $\%$ \\
\hline & Already know & 46 & 67.6 \\
$\begin{array}{l}\text { Knowing the } \\
\text { aspects of }\end{array}$ & Just heard of it & 18 & 26.5 \\
management & & 4 & \\
& Don't know & 68 & 5.9 \\
Total & & & 100 \\
\hline \hline
\end{tabular}

Table 2 shows that $67.6 \%$ of the artisans have known the aspects of management, while $26.5 \%$ other just knew about the management aspects when they filled in the questionnaires and the remaining 5.9\% have not known about them yet. It can be concluded that almost all of the woodcraft artisans have already known about the management aspects comprising of programming, directing, and organizing processes. 
TABLE 3. The knowledge level of woodcraft artisans in planning

\begin{tabular}{llcc}
\hline \hline Item & Statement & Amount of Respondents & $\%$ \\
\hline & Already know & 54 & 79.4 \\
$\begin{array}{l}\text { Knowing the } \\
\text { definition of } \\
\text { planning }\end{array}$ & Just heard of it & 7 & 10.3 \\
& Don't know & 7 & 10.3 \\
Total & & 68 & 100 \\
\hline \hline
\end{tabular}

The data of Table 3 show that $79.5 \%$ of the artisans have known about planning as an important step in defining the achieving goals. There are $10.3 \%$ artisans who just heard about it when they filled in the questionnaires and $10.3 \%$ of them who have not known about it yet.

By viewing the planning aspect of management, there are $67.6 \%$ artisans who have known the importance of planning which is to reduce the uncertainty. There are $14.8 \%$ artisans who just know of it and $17.6 \%$ who do not know of it.

One function of planning is to focus on the goal. There are $67.6 \%$ artisans who have known of this benefit, $22.1 \%$ artisans who just heard about it when they filled in the questionnaires and $10.3 \%$ of them who have no idea about it.

The benefits of planning for artisans are to decide the activities, arrange the time, and to make a schedule. $61.8 \%$ artisans had understood the function of planning while $23.5 \%$ artisans just heard about it when they filled in the questionnaires. There are still $14.7 \%$ artisans who do not know about its function.

Based on the data, it can be concluded that the average of the management knowledge level of planning is $69.1 \%$ for knowing the planning concept and its benefit in woodcraft business management. The number belongs to adequate category since the artisans who have not known the planning aspect are $30.9 \%$. There are even artisans who do not have a business plan, as shown in the table of reasons below.

TABLE 4 . The reasons why the artisans do not arrange business planning

\begin{tabular}{ll}
\hline \hline No & Reasons \\
\hline 1. & The business has not been managed well yet \\
2. & The business is still in small scale \\
3. & The owner is not able to make business planning \\
4. & The owner has not known about planning yet \\
5. & The lack of human resources \\
6. & A modest perception in running business \\
7 & The owners run the businesses by themselves \\
8. & Planning is regarded as unimportant \\
9. & The business has not been maximally managed yet \\
\hline \hline
\end{tabular}

Even so, some artisans have already understood about the organizing concept, as shown in the table below. 
TABLE 5. The knowledge level of woodcraft artisans in organizing

\begin{tabular}{llcc}
\hline \hline Item & Statement & Amount of Respondents & $\%$ \\
\hline & Already know & 42 & 63.2 \\
$\begin{array}{l}\text { Knowing the } \\
\text { definition of }\end{array}$ & Just heard of it & 19 & 28 \\
organization & & & \\
& Don't know & 6 & 8.8 \\
Total & & 67 & 100 \\
\hline \hline
\end{tabular}

Table 5 shows that many artisans have already understood the organizing concept, which is an effort in organizing the business to be used at its best. $63.2 \%$ artisans had known the concept while $28 \%$ artisans just heard about it when they filled in the questionnaires and $8.8 \%$ other have not known about it yet.

$61.2 \%$ artisans have known about the function of organizing. There are $26.9 \%$ other who have not known of it yet, and the remaining $11.9 \%$ artisans still have no idea about the function of a business organization.

There are $60.2 \%$ artisans who have known about the kinds and forms of business organization. Meanwhile, $26.5 \%$ artisans just heard about it, and $13.2 \%$ other do not understand it.

The average number of the organizing knowledge level of the artisans is $61.5 \%$, which can be categorized as adequate. It can be concluded that the knowledge level of the artisans in organizing aspect as the component of management is at an adequate level. Meanwhile, $38.5 \%$ artisans still have no idea of the aspect of woodcraft business management. In practical business, there are reasons why they have not conducted it yet. The table below shows them.

TABLE 6. The reasons why the artisans have not conducted organizing aspect

\begin{tabular}{ll}
\hline \hline No & Reasons \\
\hline 1. & The business is still in small scale \\
2. & The lack of human resources \\
3. & Small number of employees \\
4. & The owners run the businesses by themselves/no employees \\
5. & The business does not run smoothly \\
6. & The owner has not known about how to apply the right organizing aspect yet \\
7 & The owner has not known about management yet \\
\hline \hline
\end{tabular}

Understanding briefing aspect has been carried out by $80.6 \%$ artisans, while $16.4 \%$ artisans just hear about it and 3\% other do not know about it.

There are $73.1 \%$ artisans who have known the components of a briefing, including instructing, training, guiding and motivating. $17.9 \%$ artisans just know about them, and the other $9 \%$ have no idea about it.

The average percentage of the knowledge level of the briefing is $76.9 \%$, and it can be categorized as good. The temporary conclusion taken from the result is many artisans already understand the meaning of briefing. However, there are artisans who just know or even do not know about it at all in $23.1 \%$ rate. 
TABLE 7. Briefing by giving instruction to the employees

\begin{tabular}{llcc}
\hline \hline Item & Statement & Amount of Respondents & $\%$ \\
\hline $\begin{array}{l}\text { Conducting } \\
\text { briefing by giving }\end{array}$ & Of course & 54 & 85.7 \\
$\begin{array}{l}\text { instruction to } \\
\text { the employees }\end{array}$ & Never & 9 & \\
Total & & 63 & 14.3 \\
\hline \hline
\end{tabular}

There are $85.7 \%$ artisans who have conducted briefing by giving instruction to the employees. Still, there are $14.3 \%$ artisans who never give instruction to their employees.

TABLE 8 . Briefing by training the employees

\begin{tabular}{llll}
\hline \hline Item & Statement & Amount of Respondents & $\%$ \\
\hline Conducting & & 41 & \\
briefing by training & Of course & 24 & 63.1 \\
the employees & Never & 65 & 36.9 \\
Total & & 100 \\
\hline \hline
\end{tabular}

Table 8 shows that $63.1 \%$ artisans have already done briefing by training the employees while $36.9 \%$ other never give training to their employees.

TABLE 9. Briefing by giving guidance to the employees

\begin{tabular}{llcc}
\hline \hline Item & Statement & Amount of Respondents & $\%$ \\
\hline $\begin{array}{l}\text { Conducting } \\
\text { briefing by by giving }\end{array}$ & Of course & 50 & 78.1 \\
guidance to the & & & \\
employees & Never & 14 & 21.9 \\
Total & & 64 & 100 \\
\hline \hline
\end{tabular}

The data in Table 9 show that $78.1 \%$ artisans have conducted briefing by giving guidance to the employees. Even so, there are $21.9 \%$ other who never do briefing by giving guidance to the employees.

TABLE 10. Briefing by giving motivation to the employees

\begin{tabular}{llcc}
\hline \hline Item & Statement & Amount of Respondents & $\%$ \\
\hline $\begin{array}{l}\text { Conducting } \\
\text { briefing by by giving } \\
\text { motivation to the }\end{array}$ & Of course & 62 & 80 \\
employees & Never & 13 & 20 \\
Total & & 74 & 100 \\
\hline \hline
\end{tabular}

Table 10 shows that $80 \%$ of the artisans have done briefing by giving motivation to the 
TABLE 11. The knowledge level of woodcraft artisans in controlling aspect

\begin{tabular}{llcc}
\hline \hline Item & Statement & Amount of Respondents & $\%$ \\
\hline & Already know & 39 & 57.3 \\
Knowing the & & & \\
definition of & Just heard of it & 21 & 30.9 \\
controlling & & & \\
& Don't know & 8 & 11.8 \\
Total & & 68 & 100 \\
\hline \hline
\end{tabular}

Table 11 shows that $57.3 \%$ artisans had already known the definition of controlling, while $30.9 \%$ other just heard about it when they filled in the questionnaires, and the remaining $11.8 \%$ artisans do not know about it.

The knowledge level in controlling aspect is categorized into low level compared with other management aspects. In practical term, the lack of this aspect is also caused by certain reasons shown in the table below.

TABLE 12. The reasons why the artisans do not conduct controlling aspect

\begin{tabular}{ll}
\hline \hline No & Reasons \\
\hline 1. & Some of the artisans do not know about the benefit \\
2. & The owners run the businesses by themselves \\
3. & Social activities preoccupy the time \\
\hline \hline
\end{tabular}

\section{Discussion}

Most of the woodcraft artisans in Gunung Kidul Regency, Yogyakarta have understood the concept and aspects of management. Many of them have known management aspects, including planning, organizing, briefing, and controlling. Nevertheless, the knowledge level belongs to an adequate level for planning and organizing aspects. The controlling aspect is categorized into a low level. The only aspect categorized as good is briefing. Hence, the knowledge level of the woodcraft artisans for management aspects is still categorized as low since out of four management aspects, the briefing is the only good aspect. The remaining three aspects cannot be categorized as good.

There are some similarities and dissimilarities compared with the educational level of the artisans from the result of the research conducted in seven Solo Raya locations, including Karanganyar, Klaten, Sragen, Boyolali, Wonogiri, Solo, and Sukoharjo. A research of Slamet Subiyantoro (2016) points out that the business management profile of traditional visual art and craft outside of urban area has dissimilarity in term of the lack of understanding the significance of planning and organizing aspects. The controlling aspect in Solo Raya locations is better than in Gunung Kidul Regency, Yogyakarta. It is because of the understanding of controlling aspect places on the lowest from all of the management aspects.

Subiyantoro (2016) states that the craft management profile in the urban area, like conducted in Solo, already belongs to a good level in planning aspect. The educational level of the artisans in the city is higher than those in the rural area; the artisans can arrange business planning since they can analyze the situation and future prospect. Regarding this matter, a better educational, knowledge, and experience levels are necessary. Most of the artisans in Gunung Kidul Regency have low education. Their last formal education is 
elementary school-some did not even graduate - and junior high school. There are few artisans who graduated from high school. Meanwhile, the activities in the society also become dominant. Thus, the business management aspects cannot be done professionally since the social activities become an obstruction collectively. The woodcraft industry has not been managed professionally yet since it is strongly affected by Javanese socio-cultural factor under the influence of Kasultanan Yogyakarta realm.

This study stands to highlight the significance of having knowledge regarding business management for woodcraft artisans. Previous studies have not discussed specifically the knowledge yet.

\section{CONCLUSION}

Based on the result and discussion, it can be concluded that the knowledge level of woodcraft artisans for basic management concept belongs to a good level (71.5\%), for business planning belongs to an adequate level (69.1\%), and business organizing is also categorized as adequate (61.5\%). Meanwhile, the knowledge level of management in the briefing aspect is in a good level (76.9\%) and for quality control belongs to a low level (57.3\%). After all, the knowledge level of management is categorized into a low level because out of four aspects, the briefing is the only good one while the other three aspects belong to the adequate and low categories. Aside from analysing the management aspects in the small and medium enterprises of woodcraft, this paper also presents the reason as the cause of those categories. It is the socio-cultural factor in the society which tends to be more socio-collective than professional. Thus, the artisans have less time to do the business management professionally. Concerning this matter, the artisans need to increase their management knowledge include the planning, organizing, briefing and controlling aspects. They also need to apply those aspects practically.

The previous researches mainly focus on management and art craft production. Thus, the impacts have not affected specifically for woodcraft artisans yet. This paper provides the information to connect the subject to the knowledge of management for artisans.

\section{LIMITATIONS AND RECOMMENDATIONS}

This study intended to further the existing literature yet it has much potential for improvement. Since, work on wood craft artisans is limited thus, the researchers employed limited data in review. More research in this domain is encouraged in future.

\section{REFERENCES}

Bogdan, Robert, and Steven J. Taylor. 1993. Kualitatif dasar-dasar penelitian. Surabaya, Indonesia: Usaha Nasional Conkright, T.A., 2015. Using the four functions of management for sustainable employee engagement. Performance Improvement, 54 , no. 8: 15-21.

Fayol, Henri. 1949. General industry and management. London, UK: Pitman and Sons, Ltd.

Hasibuan, Malayu SP. 2002. The management of human resources. Jakarta, Indonesia: PT. Bumi Aksara.

Koontz, Harold, O'Donnell, Cyril, and Weihrich Heinz. 1991. Essentials of management. Jakarta, Indonesia: Erlangga.

Miles, Matthew B., and Michael Huberman A. 1984. Qualitative data analysis: A sourcebook of new methods. Beverly Hills, CA: Sage Publications.

Nasution, N. 1998. Naturalistic qualitative research. Bandung, Indonesia: Tarsito.

Nurkhasanah. 2002. Loro blonyo art craft in wonosari. Surakarta, Indonesia: UNS.

Rushartono, A. 1996. A comparative study of classic loro blonyo statue in Yogyakarta and Surakarta styles. Yogyakarta, Indonesia: ISI.

Spradley, JP. 1979. The ethnographic interview. New York, NY: Holt, Rinehart and Winston.

Spradley, JP. 1980. Participant Observation. New York, NY: Holt, Rinehart \& Winstons. 
Subiyantoro, S., and Aniek H. 2005. The significance of loro blonyo statue in traditional javanese context. Surakarta, Indonesia: LPPM UNS.

Subiyantoro, S., and Sulistyo ET. 2007. The form and style identification of loro blonyo statue as an effort in conserv- ing javanese cultural asset. Surakarta, Indonesia: LPPM UNS.

Subiyantoro, S., and Aniek H. 2012. An ethnic-based souvenir model development of loro blonyo art craft to increase the economic value of the artisans. Surakarta, Indonesia: LPPM UNS.

Subiyantoro, S. 2016. The management of traditional art craft: An analytic art etnography. Surakarta, Indonesia: LPPM UNS.

Sulistya, ET., Subiyantoro S., and Yulianto N. 2015. Product packaging model development of loro blonyo art craft in bobung village, gunung kidul regency, Yogyakarta. Surakarta, Indonesia: LPPM UNS.

Terry, GR. 1993. The principles of management. Jakarta, Indonesia: Bumi Aksara.

— This article does not have any appendix. - 